\section{Favism in the African type of glucose-6-phosphate dehydrogenase deficiency $\left(\mathbf{A}^{-}\right)$}

Silvana Galiano, Gian Franco Gaetani, Arrigo Barabino, Franco Cottafava, Helen Zeitlin, Margaret Town, Lucio Luzzatto

Division of Haematology, University of Genoa, Italy Silvana Galiano, BSC, senior technologist

Gian Franco Gaetani, MD, associate professor of

haematology

Department of Paediatrics, G Gaslini Institute, Genoa, Italy

Arrigo Barabino, MD, assistant

Franco Cottafava, MD, associate professor

\section{Alexandra Hospital, Redditch B98 7UB \\ Helen Zeitlin, MRCPATH, \\ consultant haematologist}

\section{Department of}

Haematology, Royal

Postgraduate Medical

School, Hammersmith

Hospital, London W12

ONN

Margaret Town, MSC, senior

scientific officer

Lucio Luzzatto, MD,

professor

Correspondence to:

Professor Luzzatto.

Br.Med 1990;300:236 $^{2}$
Susceptibility to haemolytic anaemia after ingestion of fava beans has been investigated extensively in the Mediterranean, but favism has also been observed in other countries ${ }^{1}$ including England, ${ }^{2}$ where variants of glucose-6-phosphate dehydrogenase other than the Mediterranean variant have been responsible. In general, all patients have very low glucose-6-phosphate dehydrogenase activity in red cells $(<5 \%$ of normal activity). Favism is widely believed not to occur in subjects with the glucose-6-phosphate dehydrogenase A variant, which has a higher residual activity $(10-20 \%$ of normal) and is present mainly in people of African who suffered typical attacks of clinical favism.

\section{Case reports}

Case 1-A 19 month old Italian boy was admitted to hospital in Genoa three days after eating fava beans. He was acutely ill and was passing dark urine. On admission his haemogloblin concentration was $50 \mathrm{~g} / \mathrm{l}$, he had reticulocytosis of $7 \%$, and a direct antiglobulin test yielded a negative result. Glucose-6-phosphate dehydrogenase activity in erythrocytes was within normal limits, but four months later it was $10 \%$ of the normal value.

Case 2-A 4 year old black boy from Venezuela was admitted to the paediatric clinic in Genoa with headache, vomiting, anaemia, and dark urine. Haemoglobin concentration was $51 \mathrm{~g} / \mathrm{l}$, and he had reticulocytosis of $9 \%$. Sixty hours earlier he had eaten fresh fava beans. During the haemolytic attack glucose-6-phosphate dehydrogenase activity was within the normal range, but five months later it was $12 \%$ of normal.

Case 3-A 6 month old girl with an English mother and Jamaican father was admitted to Alexandra Hospital, Worcestershire, with a 24 hour history of jaundice, pallor, and dark urine. Haemoglobin concentration was $66 \mathrm{~g} / \mathrm{l}$, and she had reticulocytosis of $5 \%$. A direct antiglobulin test yielded a negative result. origin. We report on three patients with the $A$ variant
She had eaten a large portion of fresh fava beans 24 hours before and on the day that the symptoms began. Glucose-6-phosphate dehydrogenase activity was within normal limits during the favism. Her father's red cell glucose-6-phosphate dehydrogenase activity was $7 \%$ of normal, and electrophoretic analysis showed a single band in the A position. We concluded that she was heterozygous for glucose-6-phosphate dehydrogenase deficiency.

\section{Comment}

In cases 2 and 3 the deficient variant of the enzyme was classified as $\mathrm{A}^{-}$on the grounds of the enzyme activity, the electrophoretic mobility, and the increase in activity during the posthaemolytic period. In case 1 the Michaelis constant and the enzyme activity on substrate analogues were also consistent with it being the $\mathrm{A}$ variant.

These observations indicate that subjects carrying glucose-6-phosphate dehydrogenase $\mathrm{A}$, including heterozygotes, can develop classic acute favism. All three patients showed a transient increase in enzyme activity to the normal range, which is recognised to occur with the A- but not the Mediterranean variant. Whether favism has not been reported in Africa because fava beans are not commonly grown there or because only a small subset of people with the A variant are susceptible remains to be established. The $\mathrm{A}^{-}$variant is not limited to Africa as it has been found in southern Italy and Spain, where a polymorphic variant previously called betica is now recognised as being $\mathrm{A}^{-}{ }^{-}{ }^{3}$ Favism has been reported in patients with glucose-6phosphate dehydrogenase betica and in one patient with glucose-6-phosphate dehydrogenase matera, now also known to be identical with the $\mathrm{A}^{-}$variant.' The increasing presence of Africans in Europe, where fava beans are popular, may lead to a greater incidence of the condition.

1 Luzzatto L, Mehta A. Glucose-6-phosphate dehydrogenase deficiency. In: Scriver C, Beaudet A, Sly W, Vall D, eds. The metabolic basis of inherited disease. Vol 2. 6th ed. New York: McGraw Hill, 1989:2237-66.

2 Holt JM, Sladdan BA. Favism in England - two more cases. Arch Dis Child 1965; $40: 271-3$

3 Beutler E, Vives-Corrons J-L, Hirono A, Prachal JT, Grader W. The molecular biology of variation in glucose-6-phosphate dehydrogenase. In: Brewer ( $\mathrm{jJ}$ ed. Red cell metabolism and function. New York: Alan R Liss (in press).

4 Calabro V, Cascone A, Malaspina P, Battistuzzi G. Glucose-6-phosphate dehydrogenase deficiency in southern Italy: a case of glucose-6-phosphate dehydrogenase deficiency in southern Italy: a case of glucose-6-phos

5 vulliamy TJ, D'Urso M, Battistuzzi G, et al. Diverse point mutations in the human glucose 6-phosphate dehydrogenase gene cause enzyme deficiency and mild or severe hemolytic anemia. Proc Natl Acad Sci USA 1988;85: and mil.

(Accepted 19 October 1989)

\section{Postneonatal mortality among illegitimate children registered by one or both parents}

\section{Ronald R Gordon}

\section{Gosfield Hall, Halstead, Essex CO9 1SF \\ Ronald R Gordon, FRCP, retired consultant \\ paediatrician}

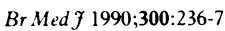

Postneonatal mortality is still higher in social class $\mathrm{V}$ than social class $I,{ }^{1}$ in illegitimate than legitimate children, and in children of younger than older mothers. ${ }^{2}$ Over a fifth of babies born in England and Wales are illegitimate. These births may be divided into two groups: those registered by both parents and those registered by only one parent. When both parents register the birth it is taken to indicate paternal support for the mother. It is often thought that having parents in a stable relationship, albeit unmarried, is as beneficial to a child as having married parents. If this is true the postneonatal mortalities, which are taken to indicate the standard of care for infants, should be similar.

\section{Methods and results}

All the data were obtained from the Office of Population Censuses and Surveys (DH3 and FM1 series (all crown copyright)). The data for 1984 and 1985 were added together and then divided by two to give an annual rate. Postneonatal mortality for the five main social classes $(\mathrm{I}-\mathrm{V})$ was compared with that for the five main maternal age groups $(<20,20-24,25-29,30$ 34 , and $\geqslant 35$ ) (figure); the rate for the social classes was based on legitimate births only and the rate for the maternal age groups on all live births. Rates by social class were compared with rates by maternal age groups. The annual numbers of postneonatal deaths were: among illegitimate children registered by one parent, 303 ; in social class $\mathrm{V}, 164$; among mothers aged $<20$, 
Mortality

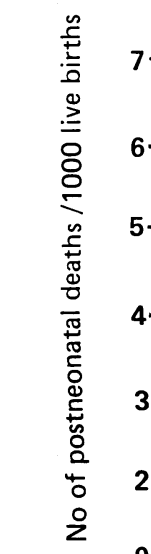

Illegitimate births (registered by one parent)

$7 \cdot 2$

Mother aged $<20$ years All illegitimate births Social class V Illegitimate births (registered by both parents)

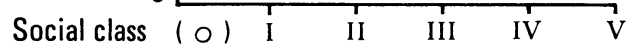

Maternal age $(\bullet) \geqslant 35 \quad 30-34 \quad 25-29 \quad 20-24 \quad<20$

Annual postneonatal mortality among legitimate live births by social class and among all live births by maternal age in England and Wales 1984-5
375; and among illegitimate children registered by both parents, 394 .

Postneonatal mortality in the three highest social groups (I to III) and the three oldest groups of mothers (those aged 25 and over) was low. The rate increased sharply in social classes IV and V and among mothers aged 20-24 and $<20$. Mean postneonatal mortality was $3 \cdot 4 / 1000$ legitimate live births, $3 \cdot 9 / 1000$ live births (legitimate and illegitimate), and 5.9/1000 illegitimate live births. When the illegitimate births were divided into those registered by one parent and those registered by both the rates were $7 \cdot 2 / 1000$ and $5 \cdot 2 / 1000$ respectively. These figures were similar to postneonatal mortality in the maternal age group $<20(7 \cdot 2 / 1000)$ and in social class $\mathrm{V}(5 \cdot 4 / 1000)$.

\section{Comment}

Postneonatal mortality was found to be $5 \cdot 9 / 1000$ for illegitimate live births. Dividing these births according to whether they were registered by one or both parents resulted in the mortality being reduced among the births registered by both parents but increased considerably among those registered by one parent. The two highest rates seen $(7 \cdot 2 / 1000$ illegitimate births registered by one parent and $6 \cdot 7 / 1000$ births to women aged $<20$ ) probably represent the same section of society, ${ }^{2}$ but this is not true for the two low rates (in social class $\mathrm{V}$ and births registered by both parents). In social class $\mathrm{V}$ the numbers of people and postneonatal deaths (only 58 in southern England in 1985) and mortality are decreasing. ${ }^{34}$ Illegitimate births registered by both parents, however, form an increasing proportion of live births. We can therefore substitute illegitimacy (even when the birth is registered by both parents) for social class $\mathrm{V}$ as an indicator of social deprivation of infants. This is especially true when illegitimacy is combined with a maternal age of less than $25 .^{2}$

Asians rarely have illegitimate children, and although half of West Indians are illegitimate, this group does not have a high postneonatal mortality. The problem of high postneonatal mortality thus seems to lie among young white parents and Pakistanis with their high rate of congenital abnormalities. ${ }^{5}$

1 Whitehead M. The health divide. London: Health Education Council, 1987:10. 2 Gordon RR, Sunderland R. Maternal age, illegitimacy, and postneonatal mortality. Br Med f 1988;297:773-4.

3 Gordon RR. Post neonatal mortality rates-Scotland. Scott Med f 1989;34 401-2.

4 Fox AJ, Goldblatt PO, Jones DR. Narrowing class differences in incomes and postneonatal mortality. In: Wilkinson RG, ed. Class and health. London: postneonatal mortality. In: Wilkinson

5 Balajaran R, Raleigh VS, Botting B. Sudden infant death syndrome and postneonatal mortality in immigrants in England and Wales. Br Med $\mathrm{f}$ 1989;298:716-20.

(Accepted 27 October 1989

\section{Districts' use of thrombolytic agents}

\author{
C J Burrell, J D Skehan, M L Cowley, \\ C W Barrett, P G Mills
}

Cardiac and Pharmacy Departments, The London Hospital, London E1 1BB C J Burrell, MRCP, lecturer J D Skehan, MRCP, senior registrar M L Cowley, MRCP, honorary senior registrar CW Barrett, MIPHARMM, district pharmaceutical officer P G Mills, FRCP consultant cardiologist

Correspondence to: Dr Burrell.

BrMed f 1990;300:237-8
Intravenous thrombolysis performed early after myocardial infarction reduces mortality ${ }^{1}$ and should be routine hospital practice unless specific contraindications exist. We examined the extent to which thrombolysis is actually used.

\section{Methods and results}

We conducted a questionnaire survey of district pharmaceutical officers by telephone in January 1989. Seventy nine English health districts were selected at random from the published list of districts with such officers. We asked the officers if thrombolysis had been used in the district; if a district policy existed and if so about content; if there was a local cardiologist; and if they had participated in trials of thrombolytic agents. Details of expenditure on thrombolysis in the last quarter of 1988 were also obtained.

All 79 districts had used thrombolysis after acute myocardial infarction, streptokinase being the preferred agent. Use of streptokinase ranged widely, from one patient being treated in two years to 40 in one month. During the survey anistreplase was not available for routine clinical use and tissue plasminogen activator, available in 44 districts, had been given to only one patient. Stocks left over from drug trials had been used in two districts.

Only 28 districts had a published policy for thrombolysis, and in 27 a policy was being prepared. Thirty six districts had participated in trials, and neither this nor the existence of a local cardiologist had influenced the development of a policy. An upper age limit was stated in 25 of the 55 policies, which ranged from 65 to 80 . A time limit for treatment was stated in 46 policies, usually six or 24 hours after the onset of symptoms. Infusion of heparin after thrombolysis was advised in 21 policies and coadministration of aspirin in 53 .

We used expenditure on streptokinase to measure treatment rates. The median treatment rate from October to December 1988 was five patients per 100000 population each month (range $0-16 \cdot 3$ ). The treatment rate was not appreciably higher in districts with a policy (either published or in preparation); those that allowed the drug to be given until 24 hours after infarction; those containing a teaching hospital; or those having a local cardiologist.

\section{Comment}

We had found previously that avoidable delays occur in giving thrombolysis. ${ }^{2}$ This had initiated the publication of a policy in our district, which was designed to facilitate rapid, reliable administration. Two thirds of the districts we surveyed had a policy, either published or being prepared; although this should increase awareness of the importance of early, accurate diagnosis and prompt treatment, it was not associated with an increased treatment rate. Clearly, the enthusiasm of doctors is important in achieving high rates. 